\title{
Understanding Ancient Farming in Tivland, North- Central Nigeria: Palaeoecological Perspectives
}

\author{
Orijemie ${ }^{1}$ and Akpo $\mathrm{E}^{2 *}$ \\ ${ }^{1}$ Department of Archaeology and Anthropology, University of Ibadan, Nigeria \\ ${ }^{2}$ Mc Donald Institute for Archaeological Research, University of Cambridge, UK
}

Submission: April 20, 2017; Published: June 16, 2017

*Corresponding author: Emuobosa Akpo, Mc Donald Institute for Archaeological Research, University of Cambridge, UK, Tel: +447514785972 , +234 8034789353; Email: orijemie5@yahoo.com, eo317@cam.ac.uk

\begin{abstract}
Sediments of a core $(0.5 \mathrm{~m})$ obtained from the floodplain of Katsina Ala River were analysed for palynomorphs and charcoal with a view to understanding human-landscape interactions in the Benue Valley, north-central Nigeria. Three phases of vegetation change were recognised. During the early phase dated to CaEt al. AD 1485-1650, environment was humid and Dioscorea spp., Arachis hypogea and Sesamum cf. indicum were cultivated. The succeeding phase was characterised by significant increase in grasses, decline in freshwater species and fluctuations in food crops. These events signalled the prevalence of dry conditions, are probably consistent with the Little Ice Age, and may have been contributory to Tiv migrations from the plains onto the hilltops. In the latest phase, although cultivation of Dioscorea spp. continued, the abundance of grasses as well as appearance of Zea mays reflected the dominance of a cereal-based agriculture. The subsequent occurrence of Citrus sp. and Mangifera indica reflected the planting of fruit trees, a farming strategy introduced into Tivland in the 20th century.
\end{abstract}

Keywords: Middle Benue valley; Farming; Dioscorea spp; Palaeoecology; Orchards; Katsina Ala

\section{Introduction}

Early occupation of the Benue Valley is known from both archaeological and oral accounts. Archaeological investigations indicated that human occupation occurred on the Tse Dura rock shelters, Ushongo during the Late Stone Age from ca. 2300 to ca. 1100 yrs B.P [1]. Afterwards, it is believed that human populations descended the hills, occupied the plains (Figure 1) until the 13th-15th centuries AD when they migrated up the hills again $[2,3]$. Tiv oral traditions claim they migrated from 'Swem', a site thought to be located in south-western Cameroon [3,4]. This site has remained elusive to archaeologists and ethnographers. Archaeological excavations in Tiv villages (Binda) located to the immediate west of the Nigerian-Cameroonian border suggest a 15th century occupation [6]. This date is consistent with those obtained from similar hilltop settlement sites to the north-west of Binda namely Mata, Mker and Ushongo. What drove the Tiv up the hills in the 13th-15th centuries? Ethnoarchaeological studies indicate that the Tiv may have been "forced" from the plains [1,7-9] due to socio-political instabilities made complex by the transatlantic slave trade [10]. Being an agrarian society, an unusually dry period such as that of the Little Ice Age [11]. could have led to crop failure, and probably contributed to the migration. This paper presents palaeoenvironmental reconstruction of aspects of the Benue Valley and humanenvironment interactions with reference to Tiv farming dynamics and migration from the 15th century till Present.

\section{Site Description}

The drilling site is located on the floodplains of the Katsina Ala River, itself a tributary of the Benue River in the Benue Valley [12]. The Katsina Ala River is one of the most important rivers in Tivland as it traverses major parts of the area (Figure 1). It serves as a source of water for domestic and irrigation purposes. The Benue Valley is characterised by granitic rocks of the Precambrian Basement Complex [13]. Aerial photography and land surveys of the area from where samples were collected indicate that Katsina Ala River has had several palaeo-channels; at least two of such channels left behind floodplains now seen as buried soils.

\section{Materials and Methods}

A sediment core $\left(\mathrm{N} 07^{\circ} \mathrm{C}, 08^{\circ} \mathrm{C}, 609^{\circ} \mathrm{C}, \mathrm{E} 009^{\circ} \mathrm{C}, 17^{\circ} \mathrm{C}, 886^{\circ} \mathrm{C}\right.$, $12 \mathrm{~m}$ asl), $50 \mathrm{~cm}$ deep $(5-55 \mathrm{~cm})$ was drilled below a water column of $30 \mathrm{~cm}$ from the floodplains of the current channel of the River Katsina Ala, Benue State, north-central Nigeria (Figure 1). In the dry season (November to February), the water level of the River 
is low with large areas in the present floodplain exposed and converted to fields where millet (Pennisetum glaucum), Sorghum (Sorghum bicolor), yams (Dioscorea spp.) and vegetables are cultivated [14]. Interviews with local people revealed that the study area had been left uncultivated for about 60-70 years, until the current planting season. The vegetation on the floodplain closest to the river consisted of Typha australis, Pistia stratiotes,
Polygonum senegalensis, Eichhornia crassipes and some Liliaceae species. On drier soils of the floodplains are Andropogon sp., Imperata sp., Ageratum conyzoides, Poaceae, Musa spp., Manihot esculenta, Ficus spp., Piliostigma thonningii, Parkia biglobosa, Commelina sp., Chromolaena odorata, Azadiractha indica, Tridax procumbens, Sida acuta and Tectonia grandis, Mangifera indica and Citrus spp.

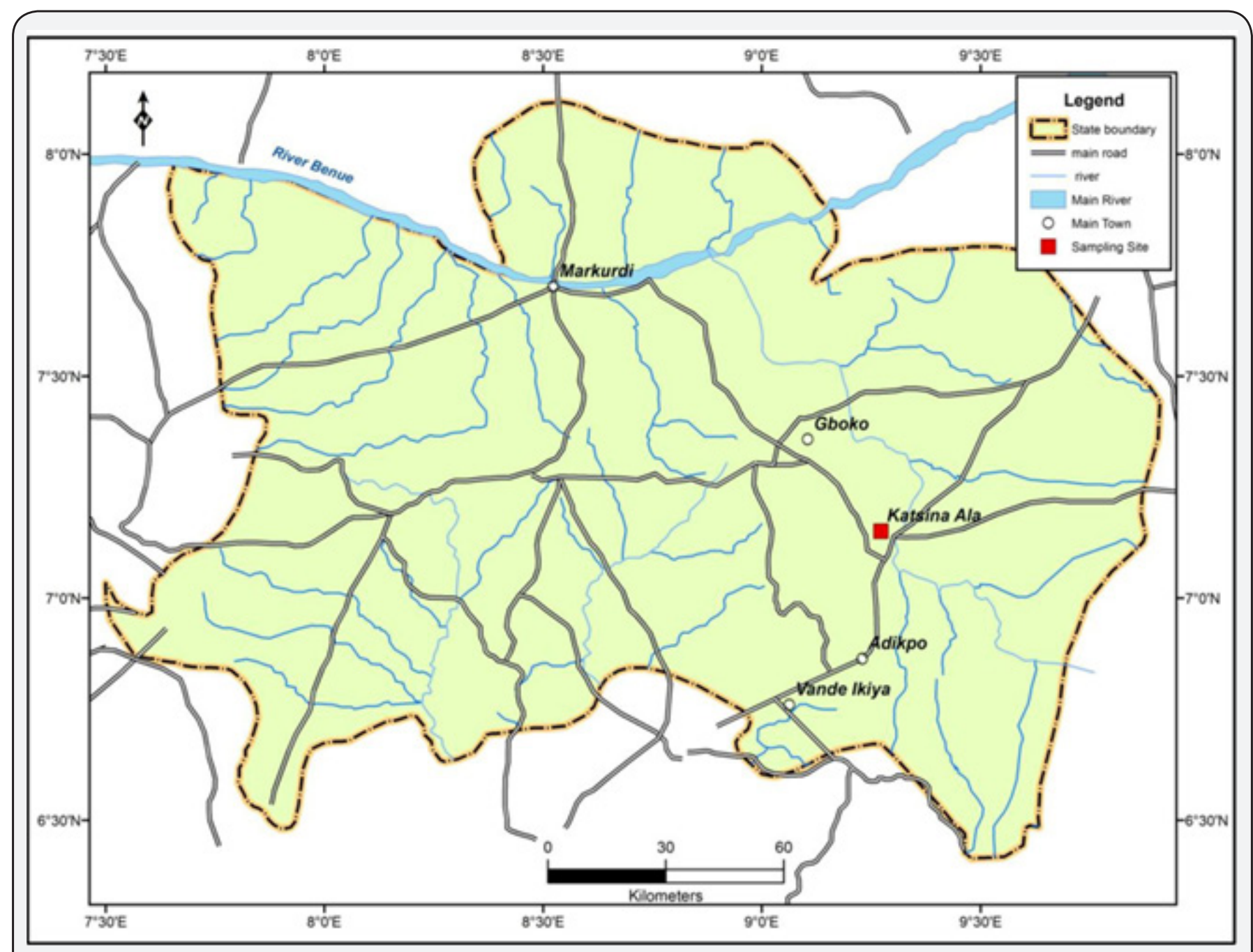

Figure 1: Map of the Benue Valley showing the sampling point and other important localities.

Sub-samples were obtained at intervals of $5 \mathrm{~cm}$; eleven subsamples were so obtained. The sizes and colours of the subsamples were documented using particle size and Munsell colour charts. For palynological analysis, sub-samples were analysed for pollen, spores, phytoliths and charcoal; each sub-sample weighing $5 \mathrm{~g}$ was treated following standard palynological techniques [15]. But without acetolysis. Acetolysis was not done because it would further destroy the presumably already fragile palynomorphs. Ten $\mathrm{ml}$ of the final residue, which was stored in $100 \%$ glycerol, was introduced onto a pair of slides and studied with a light microscope at both $\mathrm{x} 40$ and $\mathrm{x} 100$. Palynomorphs were identified to the lowest possible taxonomic level based on reference collections in the Palynology Laboratory at the Department of Archaeology and Anthropology, University of Ibadan, Nigeria as well as published literature [16,17], fungal spores were identified using van[18]. While phytoliths were identified using Barboni et aet al. [19,20], Strömberg (2004) and Zhang et aet al. [21]. Pollen diagram (Figure 2) was prepared with TILIA software and pollen zones recognised with CONISS (Grimm 2011). A soil sample from $55 \mathrm{~cm}$ of the sediment core was sent to Beta Analytic Miami, USA for AMS dating. 


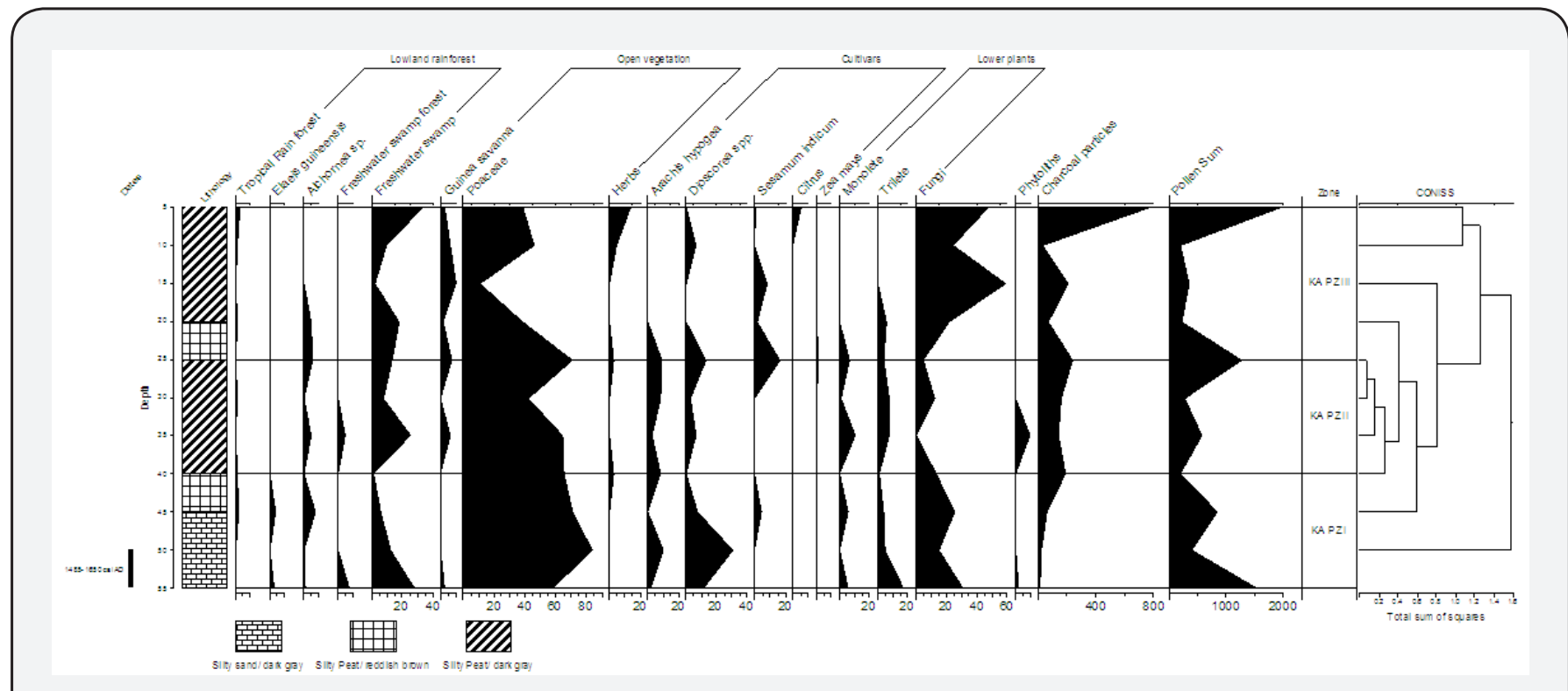

Figure 1: Map of the Benue Valley showing the sampling point and other important localities.

\section{Results}

\section{Sediment accumulation}

Accumulation of sediments at the lowest end of the core $(55 \mathrm{~cm})$ appeared to have occurred at a relatively fast rate which accounted for the loose nature of the samples. The subsequent predominance of silty peat, absence of sands and any hiatuse in the sediment core from levels $45 \mathrm{~cm}$ to $5 \mathrm{~cm}$ indicate uninterrupted and slow sedimentation and fluvial transport. At $40-45 \mathrm{~cm}$, there appears to have been some environmental disturbance evidenced by an abrupt change in soil colour from dark gray to brown with red inclusions the latter possibly being iron oxide. These changes point to an oxidation process which may have been likely caused by dry conditions. Similar change in soil colour was noted at $15-20 \mathrm{~cm}$, an indication that similar environmental conditions at $40-45 \mathrm{~cm}$ re-occurred when sediments from the former levels were deposited.

\section{Palynological and charcoal records}

Charcoal particles increased from the lowest through to the upper levels; they were generally dark in colour except at 20$25 \mathrm{~cm}$ where they were opaque and longitudinally elongated. Ninety six palynomorph types were recognised; pollen sums of duplicate slides ranged from 210 to 1967 and pollen concentration was between 8,400 palynomorphs/g and 78, 680 palynomorphs/gר. The pollen record is dominated by Pollen (58; 60.4\%); CONISS analysis yielded three pollen zones namely PZ KA I (55-40 cm), PZ KA II $(40-25 \mathrm{~cm})$ and PZ KA III $(25-5 \mathrm{~cm})$. The sample from $55 \mathrm{~cm}$ produced a date of Caet al. AD 14851650 (310 30 BP caet al.; Caet al. 465-300 BP) (Beta 444814).

\section{Interpretation}

\section{Pollen zone KA I (55-40cm) Cal. AD 1485-1650}

This zone was dominated by Dioscorea spp. (13.8-30.7\%), Arachis hypogea (0.9-10.2\%), and Poaceae (39.9-85.6\%). Freshwater species/ aquatics (8.7-21.7\%) were diverse; ferns were fairly abundant (5-21.9\%), freshwater swamp forest species were low in occurrence $(0.9 \%)$ while Guinea savanna taxa were present $(6.1 \%)$. Secondary forest species (Alchornea and Elaeis guineensis) fluctuated (5.0-14.9\%). Bilobed (0.9\%) and tuberculate $(0.9 \%)$ phytoliths were also present, albeit in small Amounts. Charcoal particles (13-24 particles/ cm3) were low in occurrence. Subsequently Poaceae (50.6\%), Sesamum cf. indicum (18.7\%) and the fungal spore Sporormiella sp. (12.4\%) became abundant; there were also increases in secondary forest (0-13.6\%). At the end of the zone, Arachis hypogea (3.518.5\%) increased while Dioscorea spp. (17.5-0\%) and Sesamum cf. indicum (18.7-0\%) were not present. Charcoal particles increased (62-184 particles $\left./ \mathrm{cm}^{3}\right)$.

\section{Pollen zone KA II (40-25cm) Post Cal. AD 1485-1650}

Dioscorea spp. (17-30.1\%) and Poaceae (41.1-73) dominated. There were fluctuations in Arachis hypogea (1.2$9.1 \%)$, freshwater species (5-18.1\%), freshwater swamp forest $(0-2.4 \%)$ and ferns $(4-13.7 \%)$. Secondary forests species (1.7$7.4 \%$ ) were few in occurrence but Alchornea $s p$. (1.7-3.9\%) increased towards the end of the zone when Sesamum cf. indicum (13.6\%), as well as few Guinea savanna species (8.5\%) were recovered. Few rainforest species $(2.4 \%)$ were present. Fungal spores (5-13.1\%) were dominated by Glomus sp. and Cercophora $s p$. Charcoal particles increased markedly 184-238 particles/ 
cm3; in addition, there was an occurrence of opaque and rodlike charcoal particles at the end of the zone coinciding with the first appearance of Zea mays (1.1\%).

\section{Pollen zone KA III $(25-5 \mathrm{~cm})$ present}

Freshwater species/aquatics (1.4-4.9\%) and freshwater species $(1.9-34 \%)$ increased significantly. Cultivars such as Arachis hypogea (5.2-0\%) decreased while Dioscorea spp. was absent. In contrast cf. Poaceae (31.1-57.9\%) increased and became dominant; Sesamum cf. indicum fluctuated (1.7-11.1\%). Zea mays was present (2.7\%); herbs (4.8\%) occurred while ferns $(10.5 \%)$ were few. Subsequently, all the cultivars except Sesamum cf. indicum decreased coinciding with marked increases in the fungal spores (58.7\%) and charcoal particles (64-206 particles/ $\mathrm{cm} 3)$. At the end of the zone, freshwater species/ aquatics, and FWSF (0-3.9\%) increased while Guinea savanna decreased (11.1-4.8\%). There were increases in Poaceae (40.6-64.8\%) and herbaceous species (4.8-21.2\%) These were accompanied by Citrus spp. (4.4\%) and Mangifera indica (0.9\%). Charcoal increased markedly reaching 780 particles/ $\mathrm{cm} 3$ at the end of the zone.

\section{Discussion}

\section{Pollen zone KA I (55-40cm) Cal. AD 1485-1650}

During the period represented by the lowest portions of the core (CaEt al. AD 1485-1650), the dominance of Poaceae, Arachis hypogea and Dioscorea spp. revealed an anthropogenic ally modified landscape. Arachis hypogea and Dioscorea spp. are thought to be low pollen producers hence the recovery of their pollen as well as their pattern of occurrence indicated that the Katsina-Ala floodplain was cultivated during the 15 th century. The dynamics of agriculture and settlement of the Tiv suggest the close relationship between the Tiv compounds and their farms [22] and Ogundele 1993. The recovery of these pollen indicate that their parent plants constituted some of the early food crops in Tivland. The recovery of bilobed and tuberculate phytoliths is significant; bilobed and tuberculate phytoliths are associated with Panicoideae grasses [19]. An indication that the landscape was open. However, Panicoid grasses are known to be "moist loving... favouring shade and/or mesic to hydric habitats" Barboni et aet al. [20]. Suggesting that aquatic bodies were also present at that time. This is supported by the recovery of freshwater species/ aquatics namely Cyperaceae, Ludwigia and Typha.

At least three different pollen types of Cyperaceae were recovered one of which is Cyperus cf. esculentus, an edible tuberous plant, commonly known as chufa or tiger nut sedge. It is commonly consumed in these parts. Freshwater swamp forest taxa were also present. Thus the moderate and subsequent high Amounts of freshwater species/aquatics as well as near absence of Guinea savanna elements suggested progressive wet environment during this period. The subsequent increase in Poaceae, and appearance of Sesamum cf. indicum and
Sporormiella sp. and Glomus sp. with concomitant decrease in cultivars and freshwater species indicated some vegetation changes. This change might probably be reflective of some dry conditions because firstly S. cf. indicum, although is a cultivar, is highly tolerant of drought-like conditions [23]. Secondly increases in Elaeis guineensis and Alchornea are characteristic of vegetation disturbance (Sowunmi 1999) while that of Guinea savanna reflects an open landscape. Thirdly, notable increases in Glomus sp. and Sporormiella sp. point to sparseness of trees and prevalence of large herbivores within the area $[24,25]$ respectively. Fourthly the soils which had hitherto been dark gray became reddish brown, an indication of oxidation (Table 1). The significance of these events with respect to Tiv migration patterns during the $14-15^{\text {th }}$ centuries AD shall be discussed shortly. After this event, there appeared to have been a change in cultivation strategy with emphases on Arachis hypogea. The occurrence of Fusarium, a fungal pathogen of pearl millet and Sorghum in West Africa [26,27]. Suggests cereal cultivation but this is not certain because of the inability to distinguish the pollen of cultivated from wild Poaceae. However, there is evidence of bush burning reflected in the increased Amount of charcoaet al.

Table 1: Litho logical description of the Katsina Ala sediment core.

\begin{tabular}{|c|c|c|c|c|}
\hline Depth cm & Layers & Sediment & Colour & Descriptions \\
\hline $5-15$ & $1 \mathrm{c}$ & Silty Peat & Dark gray & Very fine grained \\
\hline $15-20$ & $2 \mathrm{~b}$ & Silty Peat & $\begin{array}{c}\text { Gray\& } \\
\text { reddish } \\
\text { brown }\end{array}$ & $\begin{array}{c}\text { Fine grained with } \\
\text { reddish inclusions }\end{array}$ \\
\hline $20-40$ & $1 \mathrm{~b}$ & Silty Peat & Dark gray & Very fine grained \\
\hline $40-45$ & $2 \mathrm{a}$ & Silty Peat & $\begin{array}{c}\text { Gray\& } \\
\text { reddish } \\
\text { brown }\end{array}$ & $\begin{array}{c}\text { Fine grained with } \\
\text { reddish inclusions }\end{array}$ \\
\hline $45-55$ & $1 \mathrm{a}$ & Silty sand & Dark gray & Very fine grained \\
\hline
\end{tabular}

\section{Pollen zone KA II (40-25cm) Post Cal. AD 1485-1650}

The dominance of Dioscorea spp., Arachis hypogea and Sesamum cf. indicum indicated that farming resumed with these crops. Their occurrence also indicated that productive farming strategies (crop rotation) were continued within a broadly humid environment based on the fair abundance of freshwater species. Despite these "favourable" conditions, the increased Amount of Poaceae, Glomus and Cercophora showed that the area was still open; rainforest was not present. It was shortly after this period that pollen of Zea mays (maize) appeared for the first time suggesting the people made efforts at broadening their food base. The cultivation (and burning) of Zea mays may be responsible for the increased Amount of charcoaet al. The sudden appearance of the opaque and shining rod-like charcoal particles at $(20-25 \mathrm{~cm})$ is unique. Hitherto, charcoal particles had been black in colour and comparatively smaller. The source and significance of these unique charcoal particles is not yet fully understood but they could have been derived from substances other than woody and tree species. Perhaps, these "new" charcoal 
particles originated from the burning of maize stalks. Indeed, the occurrence of these "new" charcoal particles coincided with the appearance of Zea mays (maize) in the pollen record. In addition, the occurrence of these "new" charcoal particles may signal Among other things the origin of man-made fires, and the adoption of a farming system consisting of crops other than Dioscorea spp., Arachis hypogea and Sesamum cf. indicum.

\section{Pollen zone KA III (25-5cm) Present}

At the beginning of this zone, there was an increase in Poaceae. It is not clear why cultivars notably Dioscorea spp. decreased. However that its decrease coincided with increase in Cercophora, a fungal spore associated with animal dung, indicated the intensification of livestock farming. A second period of environmental disturbance occurred at $15-20 \mathrm{~cm}$ where there were marked decline in crops (except Sesamum cf. indicum) as well as in aquatics and Poaceae. In contrast, there were increases in Canthium, Gossypium and Merremia which grow mainly on abandoned fields. The significant increase in Coniochaeta cf. ligniaria indicated a high density of domesticated animals [25]. Hence it seems most likely that occupants of the floodplain of the Katsina Ala River engaged in livestock keeping during a time of environmental stress and/or when "traditional" crops failed or had poor yields. At the end of this zone, freshwater species increased indicating prevalence of humid climate.

In the latter part of the zone, Guinea savanna elements such as Cissus quadrangularis, Nauclea sp. and Uapaca sp. exhibited significant increase as well as pollen of herbaceous plants (Amaranthaceae/Chenopodiaceae and Asteraceae) associated with farming. There were decreases in Dioscorea spp., Sesamum cf. indicum and Arachis hypogea suggesting probable reduced emphasis on these food crops. Although this might also be due to pollen preservation bias but yam cultivation in Tivland, particularly in the Katsina Ala-Ushongo areas is generally on the decrease probably a result of the introduction of cassava (Manihot esculenta) and nuisance of new and stubborn weeds associated with the latter crop [23]. documented the downward trend in the importance of benniseed in Tivland in the last century. This change in farming might not be unconnected with the introduction of new farming system where exotic fruit trees such as Citrus spp. and Mangifera indica are cultivated. This farming strategy is reflected in the pollen record with the occurrence of Citrus spp. and Mangifera indica as well as the abundance of Lasiodiplodia cf. theobromae. The abundance of the fungal spore Lasiodiplodia cf. theobromae (6.9-16.7\%) at the topmost level $(10 \mathrm{~cm}-5 \mathrm{~cm})$ is significant; $L$. cf. theobromae is a major cause of rot and dieback disease (Úrbez-Torres et aet al. 2007) in Citrus spp. and Mangifera indica (Khanzada et aet al. 2005). These fruit trees were introduced by the Dutch Christian Reform Mission (DCRM) in the 20th century. However, this new farming system of orchard planting reduces the size of arable land available for the cultivation of food crops and alters the traditional fallow practice of the Tiv. This forces farmers to engage in continuous cultivation of a piece of land, ultimately complicating soil fertility regime. This practice partly accounts for the undesired poor crop yields currently experienced in Tivland, a phenomenon which has the capacity of causing food insecurity in the long run.

\section{Introduction of cereals into the Benue valley}

Pennisetum and Sorghum are believed to have been domesticated in the Sudan/Sahel zones of West Africa D'Andrea et aet al. [28-32]. How did they reach the Benue Valley? There are at least two areas from where millet might have been introduced to Tivland which correspond in part to Blench (2010)'s secondary areas of the diversification of pearl millet. The first is the Nok area in north-central Nigeria to the north of Tivland. Archaeobotanical studies in Nok indicate the occurrence of millets there at ca. 800-450 yrs cal BC [33]. The recovery of Nok terracotta in the Katsina Ala dated to $400 \pm 125$ cal BC (Fagg, 2014) suggests some socio-cultural connections between the former and the latter apparently in the distant past. The other area is Bwambé-Sommet in southern Cameroon where domesticated millet (Pennisetum glaucum) has been dated to 400-200 BC [34]. Aspects of Tiv oral traditions state that their ancestral home, Swem, is located to the immediate north of the Bwambé-Sommet area in southern Cameroon [9]. The name for pearl millet in Tiv, Amine, does not seem linguistically related to common Bantu terms for pearl millet i.e. *-cángü and *-bèdé neither does it bear any resemblance to Maiwa the Hausa word for millet [31]. Rather Amine appears linguistically related to àmên, the name for millet in Anib of Plateau State, north-central Nigeria. A loosely related term is Amo, the word for millet in Jili, a language also spoken in the Plateau. Therefore on the basis of artefact (i.e. Nok terracotta) and limited linguistic evidence, the Plateau region of north-central Nigeria may have played a major role in the introduction of millet into Tivland than Cameroon or Hausa land.

In contrast, the high degree of similarity between the Hausa (daawàr; dawa) [35]. And Tiv words for Sorghum (wua) indicate that the crop was most likely introduced into the Benue valley from the former area. This inference is strengthened by the ancient tradition of Sorghum domestication in Daima [36]. And the Lake Chad area in north-eastern Nigeria [30,32,37]. The appearance of the pollen of maize (Zea mays) in the pollen record (at $25 \mathrm{~cm}$ of the sediment core) is consistent with Tiv traditions that it was introduced after millet and Sorghum. There is substantial linguistic evidence that maize when introduced into an area is usually called "Sorghum with an epithet" (Willet 1962:7) or guinea-corn with an epithet [35]. The name for maize in Tiv is Ikyúlèké a term linguistically different from Milho, the Portuguese term for maize, and excludes a coastal introduction of the crop. Ikyúlèké is derived from Kuuli (+ke). Kuuli is also used by Cross-River, Idomoid and Platoid languages for maize. These peoples probably obtained Maize from the Jukun or some northern groups close to or synonymous with 
the Hausas of northern Nigeria Blench et aet al. [35]. Thus maize was most likely introduced into the Benue Valley from some northern contacts probably Platoid-speaking peoples, an idea that contrasts the widely held view of a Portuguese introduction of maize into most parts of Nigeria. It must however be stated that the linguistic relationships advanced above are based on surface phonetic similarities. Systematic historical linguistic reconstructions of these crops and their stem/root words may produce evidence to the contrary in the future.

\section{Migration from the Benue valley onto the hills- palaeoecological clues}

Factors which could have influenced the migration of the Tiv include epidemic, political instability, climate change and crop failure. Events of epidemic are not yet known from the relatively few ethnographic studies carried out in the Benue Valley. Archaeological investigations of the settlement patterns on the hills indicate that the Tiv were constrained by space hence adopted several strategies in managing and coping with the difficulties presented by the landscape (Ogundele 2005). In addition, it had been stated that the hills were not originally occupied because of farming purposes [2]. The AD 13th-15th centuries occupation period of these hills coincided in part with two major events namely the Trans-Atlantic slave trade and Little Ice Age (LIA). The Trans-Atlantic slave trade occurred between the 15th and early 20th centuries; it led to political instabilities in West and Central African sub-region, some of the impacts of which was the displacement of populations in the Benue Valley [10]. As well as other areas in Nigeria (Ogundiran \& Falola 2010). The LIA which occurred at ca. AD 1450-1890 is thought to have been a period of cold and dry climate. There is however evidence that during the LIA, conditions were very dry in the Central parts of Africa [11]. But wet in East Africa [38]. From AD 1400-1750 and ca. AD 1270-1850 respectively. [39] Opined, based on sediment logical and mineralogical analyses of the upper sediments of River Tete, a tributary of Katsina Ala, that drier and cooler climate occurred contemporaneously with the occupation of uphill sites of Mata at ca. $310 \pm 150$ B.P. and Ushongo hills at ca. $580 \pm 130$ B.P.

Evidence from the present study indicates that shortly after caet al. AD 1485-1650, sediments became reddish brown in colour which is suggestive of oxidation and probable reduced rainfalet al. In addition, there were marked increases in grasses accompanied by disappearance of freshwater swamp forest species, and decreases in freshwater species and in crops (Dioscorea spp. and Arachis hypogea) except Sesamum cf. indicum which is tolerant of dry conditions. These litho logical and vegetation changes are consistent with dry environmental conditions. Marked increases in the dung-dwelling fungus Sporormiella and of Glomus sp. suggest a spread of herbivores within the area which was also largely devoid of tree cover. Presumably, under the inferred dry conditions, there would have been crop failure culminating in the temporary abandonment of the area [40]. Hence, there is high probability that the herbivores which colonised the valley were wild rather than domesticated forms, the droppings of which were responsible for the significant increase in Sporormiella. On the other hand, if it is assumed that there was a shift to livestock keeping, it is difficult to conceive of such a practice without complementary input from farming. In fact, the absence of Coniochaeta cf. ligniaria, a fungus indicative of high density of domesticated animals [25], corroborates the wild herbivore inference. However the dry condition probably did not last long $(45-40 \mathrm{~cm})$ and was succeeded by a wet period during which cultivars and humid-loving plants subsequently flourished [41].

\section{Conclusion}

Pollen analysis of a sediment core from floodplain of the Katsina Ala River in the Benue Valley was carried out. The main aim was to ascertain early plant resources available to the people, as well as the dynamic ecological settings under which they were cultivated. Three phases were identified in the sediments from the sediment core namely an early wet phase dated to Caet al. AD 1485-1650, followed by a dry phase, which was succeeded by a latest humid phase with human presence recorded in all the phases [42,43]. Cultivars included Dioscorea spp. (yams), Arachis hypogea (groundnut) and Sesamum cf. indicum (benniseed); wild plants including Cyprus cf. esculentus (chufa/ tiger nuts) were probably collected. In the dry phase crops failed but grasses dominated suggesting a more open landscape $[44,45]$. It is inferred that it was under this dry environmental condition coupled with socio-political unrest that the Tiv migrated uphill in the 13th-15th centuries AD. During the third and latest phase, conditions ameliorated, Zea mays (maize) appeared but Dioscorea spp., Arachis hypogea and Sesamum cf. indicum declined. The subsequent appearance of Citrus spp. and Mangifera indica pollen revealed the introduction of a new farming system (orchards) which is centred on the cultivation of fruit trees. The pollen records agree with the oral tradition of the Tiv particularly with regard to farming dynamics the Benue Valley and associated crops as well as the recent introduction of "exotic" crops [46].

\section{Acknowledgement}

The author is grateful to the African Farming Network under which the fieldwork was carried out, and to the ParAmount ruler of Katsina Ala, HRH Benjamin Fezanga Wombo for permission to drill for sediment cores. Thanks are also due to Dr. Jonathan Ndera and Mr. Richard Chia, and Mr. P. C. Opara for field, and technical assistance respectively.

\section{References}

1. Andah BW (1983) The Bantu Homeland Project: Ethnoarchaeological investigations in parts of the Benue Valley Region. West African Journal of Archaeology 13: 23-60.

2. Folorunso CA, Andah BW, Sowunmi MA, Okpoko AI (1998) The compound of the Tiv in Benue State Nigeria: The Reality of Ethnoarchaeology In Andah, B.W. AFRICA: The Challenge of Archaeology Heinemann Educational Books (Nigeria) pp. 235-255. 


\section{Global Journal of Archaeology \& Anthropology}

3. Ogundele SO (2005) Ethnoarchaeology of Domestic Space and Spatial Behaviour Among the Tiv and Ungwai of Central Nigeria. The African Archaeological Review 22 (1): 25-54.

4. Chia RT (2013) Tiv Origin and Migrations: Myth Versus Reality. Journal of Tourism and Heritage Studies 2(2): 24-35.

5. Ndera JD (2013) Archaeological Perspectives on the Origins and Migrations of the Tiv in the Benue Valley of Nigeria. Journal of Heritage studies 2(2): 14-23.

6. Ogundele SO (1990) Archaeological investigations into aspects of Tiv settlement history. Unpublished PhD Thesis, University of Ibadan, Ibadan.

7. Andah BW (1993) Identifying early farming traditions of West Africa In: Shaw T, Sinclair P, Andah B and Okpoko A (eds.), The Archaeology of Africa. Food, Metals and Towns Routledge, London, pp. 240-254.

8. Andah BW (1998) The Question of the Bantu Cultural Landscape in African History In: Andah, B. W., Sowunmi, M. A., Okpoko, A. I. \& Folorunso, C. A. (eds.), Heinemann Educational Books (Nigeria) Plc AFRICA: The Challenge of Archaeology pp 201-234.

9. Gundu ZA (2013) an Appraisal of Archaeology in the Middle Benue Valley: 1951-2011. West African Journal of Archaeology 43 (1\&2): 83104

10. Folorunso CA (2006) The Trans-Atlantic slave trade and local traditions of slavery in West African Hinterlands: The Tivland example. In: Havisser JB \& MacDonald K.C (eds.) Confronting Social Issues in the Diaspora, London \& New York, University College London Press, pp. 237-245.

11. Russell JM \& Johnson TC (2007) Little Ice Age drought in equatoria Africa: Intertropical Convergence Zone migrations and El NiñoSouthern Oscillation variability. Geology 35(1): 21-24.

12. Malu SP, Edem CA, Ita BI (2015) Chemical Characterization of silica sand deposit from River Katsina-Ala, North Central Region of Nigeria. Global Journal of Pure and Applied Physics 3(1): 26-37.

13. Obiora SC (2012) Chemical Characterization and Tectonic Evolution of Hornblende-Biotite Granitoids from The Precambrian Basement Complex around Ityowanye and Katsina-Ala, Southeastern Nigeria. Journal of Mining and Geology 48(1): 13-29.

14. Dam PD (2012) Dry Season Vegetable Farming In The Floodplains of River Katsina-Ala in Katsina-Ala Town of Benue State, Nigeria. Journal of Environmental Issues and Agriculture in Developing Countries 4 (1): 18-23.

15. Faegri K \& Iversen J (1988) Textbook of Pollen Analysis. John Wiley and Sons Alden Press London.

16. Sowunmi MA (1973) Pollen of Nigerian Plants I Woody Species. Grana 13(3): 145-186.

17. Sowunmi MA (1995) Pollen of Nigerian Plants II Woody Species. Grana 34(2): 120-141.

18. Gelorini V, Verbeken A, van Geel B, Ccoquyt C, Verschuren D, et aet al. (2011) Modern non-pollen palynomorphs fropm East African lake sediments. Review of Palaeobotany and Palynology 164(3-4): 143-173.

19. Barboni D, Bremond L, Bonnefille R (2007) Comparative study of modern phytolith assemblages from inter-tropical Africa Palaeogeography Palaeoclimatology Palaeoecology 246(2007): 454470

20. Barboni D, Ashley GM, Dominguez-Rodrigo M, Bunn HT, Mabulla AZP, et aet al. (2010) Phytoliths infer locally dense and heterogeneous palaeovegetation at FLK North and surrounding localities during upper Bed I time, Olduvai Gorge, Tanzania. Quaternary Research 74(3): 344-354.

21. Zhang J, Lu H, Wu N, Li F, Yang X, et aet al. (2010) Phytolith evidence for rice cultivation and spread in Mid-Late Neolithic archaeological sites in central North China. Boreas 39(3): 592-602.

22. Folorunso CA, Ogundele SO (1993) Agriculture and settlement Among the Tiv of Nigeria: some ethnoarchaeological observations In: Shaw T, Sinclair TP, Andah B, Okpoko AI (eds.) The Archaeology of Africa. Food, Metals and Towns Routledge, London, pp. 274-288.

23. Dorward DC (1975) An Unknown Nigerian Export: Tiv Benniseed Production, 1900-1960. Journal of African History 16 (3): 431-459.

24. Davis OK, Shafer DS (2006) Sporormiella fungal spores, a palynological means of detecting herbivore density. Palaeogeography, Palaeoclimatology, Palaeoecology 237(1): 40-50.

25. van Geel B, Gelorini V, Lyaruu A, ptroot A, Rucina, S, et aet al. (2011) Diversity and ecology of tropical African fungal spores from a 25,000-year palaeoenvironmental record in southeastern Kenya. Rev Palaeobot Palynology 164(3-4): 174-190.

26. Abdulsalaam S, Shenge KC (2011) Seed borne pathogens on farmersaved Sorghum. Journal of Stored products and post harvest Research 2(2): 24-28.

27.Zida PE, Sereme P, Leth V, Sankara P, Somda I, et aet al. (2008) Importance of seed-borne Fungi of Sorghum and Pearl millet in Burkina Faso and their control using plants extracts. Pakistan Journal of Biological Sciences 11: 321-331.

28. D’Andrea AC, Klee M, Casey J (2001) Archaeological evidence for pearl millet (Pennisetum glaucum) in Sub-Saharan West Africa. Antiquity 75(288): 341-348.

29. D’Andrea AC, Casey J (2002) Pearl millet and Kintampo subsistence. African Archaeological Review 19(3): 147-173.

30. Breunig P, Neumann K (2002) from hunters and gatherers to food producers: new archaeological and archaeobotanical evidence from the West African Saheet al. Droughts, Food and Culture, New York, Boston, Dordrecht, London, Moscow, pp. 123-156.

31. Blench R (2010) the contribution of vernacular names for pearl millet to its early history in Africa and Asia. Paper prepared for the Rihn Symposium 'Small Millets in Africa and Asia' Tokyo September 1920th, 2010.

32. Pelling R (2014) Patterns in the Archaeobotany of Africa: Developing Database for North Africa, The Sahara and The Sahel In: Stevens CJ, Nixon S, Murray MA, Fuller D (eds.) Archaeology of African Plant Use, Walnut Creek, California, pp. 205-224.

33. Kahlheber S, Höhn A, Rupp N (2009) Archaeobotanical Studies at Nok sites: an Interim Report. Nyame Akuma 71: 2-17.

34. Kahlheber S, Höhn A, Neumann K (2014) Plant and Land use in Southern Cameroon 400 BCE- 400 CE In Stevens CJ, Nixon S, Murray MA, Fuller D (eds.) Archaeology of African Plant Use, Walnut Creek, California, pp. 113-128.

35. Blench RM, Williamson K, Connell B (1994) the diffusion of maize in Nigeria: A historical and linguistic investigation. Sprache und Geschichte in Afrika 15(1994): 9-46.

36. Connah G (1981) Three thousand years in Africa: Man and His Environment in the Lake Chad Region of Nigeria. Cambridge University Press, Cambridge, pp. 268.

37. Magnavita C (2002) Recent archaeological finds of domesticated Sorghum bicolor in the Lake Chad region Nyame Akuma 57: 14-20.

38. Verschuren D, Laird KR, Cumming BF (2000) Rainfall and drought in equatorial east Africa during the past 1,100 years. Nature 403: 410414.

39. Tubosun BJ (1995) Geo-Archaeological Investigations in Adikpo area of Katsina-Ala River basin, Benue State, Nigeria. Unpublished PhD Thesis, University of Ibadan, Ibadan. 
40. Blench R (2014) African Agricultural Tools: implications of Synchronic Ethnography for Agrarian History In: Stevens CJ, Nixon S, Murray MA, Fuller D (eds.), Archaeology of African Plant Use, Walnut Creek, California, pp. 243-257.

41.Jan F, Schüler L, Behling H (2015) Trends of pollen grain size variation in C3 and C4 Poaceae species using pollen morphology for future assessment of grassland ecosystem dynamics Grana 54 (2): 129-145.

42. Khanzada MA, Lodhi AM, Shahzad S (2005) Chemical control of Lasiodiplodia theobromae, the causal agent of mango decline in Sindh. Pak J Bot 37(4): 1023-1030.

43. Piperno DR (1994) Phytolith and charcoal evidence for prehistoric slash-and-burn agriculture in the Darien rain forest of Panama. The Holocene 4(3): 321-325.

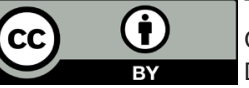

This work is licensed under Creative Commons Attribution 4.0 Licens

DOI: 10.19080/GJAA.2017.01.555569
44. Úrbez-Torres JR, Leavitt GM, Guerrero JC, Guevara J, Gubler WD, et aet al. (2008) Identification and Pathogenicity of Lasiodiplodia theobromae and Diplodia seriata, the Causal Agents of Bot Canker Disease of Grapevines in Mexico. Plant Dis 92(4): 519-529.

45. Willet F (1962) the Introduction of Maize into West Africa: An Assessment of Recent Evidence. Africa: Journal of the International African Institute 32 (1): 1-13.

46. Zuloaga FO, Morrone O, Davidse G, Pennington SJ (2007) Classification and Biogeography of Panicoideae (Poaceae) in the New World. Aliso 23(1): 503-529.

\section{Your next submission with Juniper Publishers will reach you the below assets}

- Quality Editorial service

- Swift Peer Review

- Reprints availability

- E-prints Service

- Manuscript Podcast for convenient understanding

- Global attainment for your research

- Manuscript accessibility in different formats

( Pdf, E-pub, Full Text, Audio)

- Unceasing customer service

Track the below URL for one-step submission

https://juniperpublishers.com/online-submission.php 